\title{
メキシレチンとプロパフェノンの血行動態に及ぼす 影響一重症左心機能低下例における検討一
}

$\begin{array}{lll}\text { 杉 村 洋 一* } & \text { 佐 藤 友 英* 武士 仁 彦* } \\ \text { 一 色 高 明* } & \text { 宮 下 英 夫* }\end{array}$

近年、抗不整脈薬による陰性変力作用が注目さ れ、様々な検討がなされているが、過去の検討は ほとんどが心機能正常例、あるいは軽度心機能低 下例に対するものである。しかし、実際に難治性 心室性不整脈に悩まされる症例は、重症心機能低 下例であることが少なくない。そこで、重症心機 能低下例の血行動態に及ぼす抗不整脈薬の影響に ついて、メキシレチンとプロパフェノンを用いて 以下の検討を行った。

対象：対象は、心不全歷を有する左室駆出率 $40 \%$ 以下の重症左心機能低下例 6 例。いずれも合 併する心室性不整脈に対し、抗不整脈薬治療を施 行中、あるいはこれから施行するという症例であ る。男性 4 例、女性 2 例で、平均年踰66 09 歳、 全 6 例の心プール法による平均左室駆出率は $26.7 \pm 8 \%$ であった。基礎心疾患は陳旧性心筋 梗塞 4 例、拡張型心筋症 2 例であった。

方法：血行動態の安定した時期にSwan-Ganz カテーテルと動脈カニューレを留置し、メキシレ チン $300 \mathrm{mg}$ あるいはプロパフェノン $300 \mathrm{mg}$ を単 回経口投与し、投与前及び投与 $60 、 90 、 120$ 、 150 分後に平均動脈圧、心拍数、右房圧、肺動脈 圧肺動脈楔入圧、心係数を測定し、翌日に他剤に ついて同様の測定を行った。また、投薬 2 時間後 と翌朝に各薬剤の血中濃度を測定した。投薬 24 時

\footnotetext{
* 帝京大学医学部第二内科

干 173 東京都板橋区加賀 2-11-1
}
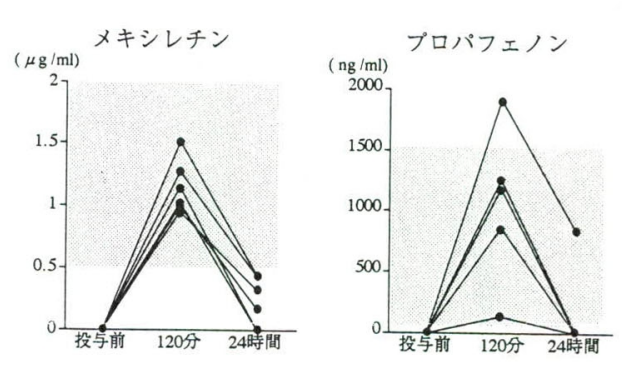

Fig. 1 薬剤血中濃度の推移

間前より抗不整脈薬、血管拡張薬、及びジギタリ スを除く強心薬は全て中止した。なお、3 例は初 日にメキシレチンを、残りの 3 例は初日にプロパ フェノンを投与した。

結果：(1)薬剂血中濃度 投薬120分後と翌日 の薬剤血中濃度を Fig. 1 に示す。グラフ中央の 枠は、各薬剤の有効血中濃度の範囲を示す。メキ シレチンは、投薬120分後には全例有効血中濃度 内に入っており、翌日には全例有効血中濃度以下 に下がった。一方、プロパフェノンも1例を除 き、投与120分後には有効血中濃度内にあり、翌 日には測定可能域以下であった。1例のみ、投薬 120分後、翌日とも高值を示した。たたしこの症 例は、初日にメキシレチン、2 日目にプロパフェ ノンを投与した群なので、メキシレチンに対する 影響はなかった。

\section{(2)メキシレチン投与による血行動態の変動}

Fig. 2 に示すように、各血行動態の指標はメ キシレチン投与開始60分後から変動を見せた。投 薬前と、血中濃度を確認した投薬120分後で比較 

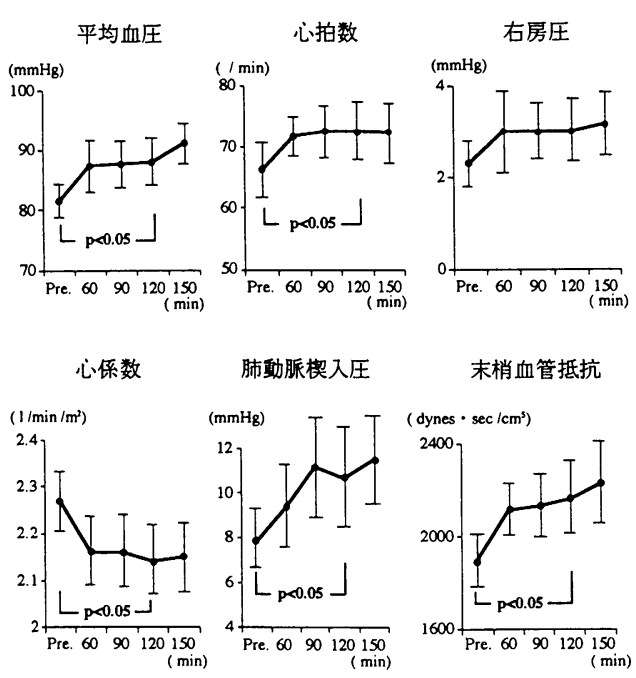

Fig. 2 メキシレチン投与による血行動態の変動

してみると、平均血圧は $82 \pm 7$ から $88 \pm 9 \mathrm{mmHg}$ へと有意に上昇し、心拍数も平均 66 から $73 / \mathrm{min}$ へと上昇した。心係数は $2.3 \pm 0.2$ から $2.1 \pm 0.2$ $1 / \mathrm{min} / \mathrm{m}^{2}$ へと有意に低下し、肺動脈楔入圧は7.8 \pm 3 から $11 \pm 6 \mathrm{mmHg}$ へと有意に上昇した。平均 血圧、右房圧、心拍出量から算出した末梢血管抵 抗は有意に上昇した。

(3)プロパフェノン投与による血行動態の変動

Fig. 3 に示すように、平均血圧、心拍数、右 房圧に有意な変動は認められず、心係数はやや低 下する傾向にあった。肺動脈楔入圧は $10 \pm 6$ から $13 \pm 7 \mathrm{mmHg}$ 一と有意に上昇した。

なお、本検討中、電解質を含め血液生化学所見 は、投薬前後で変動を認めなかった。また、心不 全発症など、検査に関連した合併症はなかった。

考案：従来の、抗不整脈薬と血行動態に関す る検討は、一回静注法による急性の変動に関する ものが多く、経口投与に関する検討は少ない。ま た経口投与に関する検討では、長期間Swan-Ganz カテーテルを留置することが実際上難しいため、 血行動態の評価に心プール法や心エコー法による 左室駆出率が用いられており、これは血行動態の 変動にあまり鋭敏とは言えない。そこで今回、 Swan-Ganz カテーテルを留置し、抗不整脈薬の 単回経口投与による血行動態の変動を検討した。
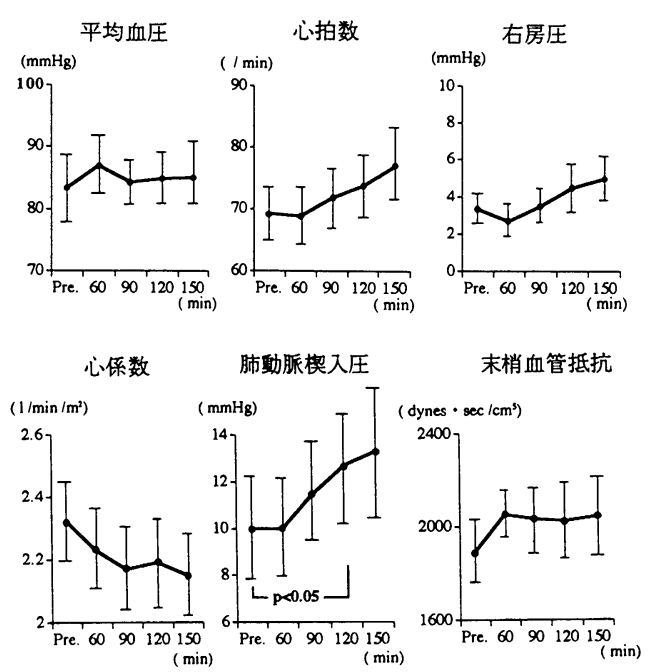

Fig. 3 プロパフェノン投与による血行動態の変動

今回の検討では、重症心機能低下例において、 メキシレチン、プロパフェノンとも、血行動態に 悪影響を及ぼした。症例数は少ないが、今回この 傾向はむしろメキシレチンに強い印象があった。 これまでの報告では、メキシレチンは血行動態に あまり悪影響を及ぼさないとされていた。しかし 過去の報告は、左心機能との関連に言及したもの は少なく、ほとんどが正常心機能例に対するもの であった。Gottliebらは、左室駆出率40\%以下 の重症心機能低下例20例における検討で、メキシ レチンは有意に心拍出量を低下させたと報告して おり"、これは我々の結果と一致している。一般 的に陰性変力作用が弱いとされているメキシレチ ンといえども、重症左心機能低下例に投与する場 合には十分な注意が必要と思われた。

粘諭：重症心機能低下例においてメキシレチ ン、プロパフェノンは、ともに血行動態に悪影響 を及ぼす可能性がある。

\section{文献}

1) Gottl i eb SS., We inberg M., Baltimore RN. Comparative Hemodynamic effects of mexiletine and quinidine in patients with severe left ventricular dysfunction: Am Heart J, 122:1368-1374 (1992). 